\title{
Student Internship for Integrated Learning in Population \& Tax and Political Parties Accountability
}

\author{
N. Zuryani \\ Sociology Department, FISIP Udayana University \\ Bali, Indonesia \\ nazrinazuryani@yahoo.com
}

\begin{abstract}
Imitating the practice of Work Integrated Learning (WIL) in Australian human capital capacity building, this research is based on student internship as a form of WIL. The aim of the research is to compile enough data and information, collected by students and their supervisors during their internships, write two text books on 1) Population and Tax; and 2) Political Party Accountability, to be used later as teaching aids. The textbooks are specifically written for elective subjects for Sociology, Political Sciences and Public Administration programs. All chapters were written by a research working group of nine lecturers, and are designed to compliment 50 hours of work experience by students at government and NGO institutions. Students who undertook the internship received a minimum of 2 hours of induction lectures before they started their internships at various institutions related to the topic area of the books and elective subjects. Twelve institutions provided placement for the interns. The research findings show an increase in the students' professional competence benefiting their future career choices and productivity and furthermore have facilitated two new textbooks, based on real-world data, that will guide future WIL programs for elective subjects about population, tax, and the accountability of political parties.
\end{abstract}

Key words: student internship, textbook, population \& tax, accountability, political parties, elective subjects

\section{INTRODUCTION}

The Faculty of Social and Political Sciences/FISIP at Udayana University first opened for new students in 2009. Two study programs of Sociology and International Relations were the pioneer programs. Since 2009, four further study programs have opened for new students; Public Administration, Political Science, Communication Science and Library Science Diploma III. In 2012, although the faculty was preparing for accreditation for each of the study programs under the Indonesian Qualification Framework (IQF), a requirement of which is that program development must take into account the need to prepare students for future career, accreditation was postponed until elective subjects were added to strengthen the programs and to provide students with increased options. Hence, this research is both designed for, and facilitated by, providing student internships vis-a-vis two new elective subjects. The resulting two new textbooks will be used as future teaching resources at the Faculty of Social and Political Science, Udayana University.

On the basis of the IQF assessment, it is recommended that FISIP Unud urgently undertake further curriculum revision. Based on an Australian Universities' approach to Work Integrated Learning (WIL), McLennan and Keating [1] explain that WIL is not just about preparing students for work and careers, it is a teaching and learning approach which has the potential to provide a rich, active and contextualized learning experience for students which contributes to their engagement in learning. With these textbooks, the students at FISIP Udayana Undiversity can choose one or both subjects as their electives and then by undertaking internships, they can take advantage of gaining an elevated level of professional competence.

\section{A. Research Method of Producing Text Books}

Both textbooks are a result of action research conducted in Bali in government departments, social institutions and private businesses such as the head offices of BPS, BKKBN, Disnaker, Dinkes, Dispenda and the DJP Bali provincial offices as well as KPU, Bawaslu, Kesbangpol, an Ombudsman's office, Public Accountants Wayan Budiartha and the head of the Democratic Party, Bali branch. The heads of these departments and institutions formed an adjunct team. The design of this research was to facilitate student internship in their fifth semester onward. The first textbook on 'Population \& Tax' measures the instructional awareness of the demographic dividend that may increase the payable taxation in Indonesia. The second textbook on 'Political Parties Accountability' measures the lack of accountability of political parties in Indonesia. As a medium of learning about social and political issues in contemporary Indonesia, these two textbooks are vital additions to existing resources. They also prepare the students to further develop their professional competence.

\section{B. Aims and Purpose of the Research}

Internships entail an experience in a workplace along with complimentary tutorials at the university. Every student benefits from both their work experience and class lectures and learns from both the adjunct team in each institution and lecturers at the university. Students' reflections on their work experience must be guided by their internship mentors at the institution in the form of a (1-2 hour) general lecture at their work places followed by group discussions. This is called human capital strengthening via an internship program.

On campus, the students discuss the case in each chapter in the textbook before they start their work 
experience. This stage is preparing the students to analyze the real situations in each institution by in depth case analysis discussed in briefing meetings and tutorials with members of the adjunct team. Students receive an integrated learning experience through participation in workplace internships interacting with real-life situations and receiving mentoring advice from lecturers and adjunct team members. The internships provide them with the means to develop professional competence before they are required to choose a final career path.

By 2016, the Indonesia Qualification Framework, KKNI, see Fig 1, has a duty to give a 1 to 9 valuation for students in workplaces who have multiple points of entry and exit into or out of an open learning system. This qualifications framework needs to be implemented, however, it cannot be presumed that the MEA (ASEAN Economic Community) will start this process soon as the Indonesian Qualifications Framework was developed in 2003 and has experienced a lag time in full implementation. It will mean that graduates of university compete with workers in the workplace who have the possibility of gaining a level 6 certificate within the Indonesian Qualification Framework as an equivalent to a bachelor degree. By 2016, the KKNI will be implemented in parallel to MEA.

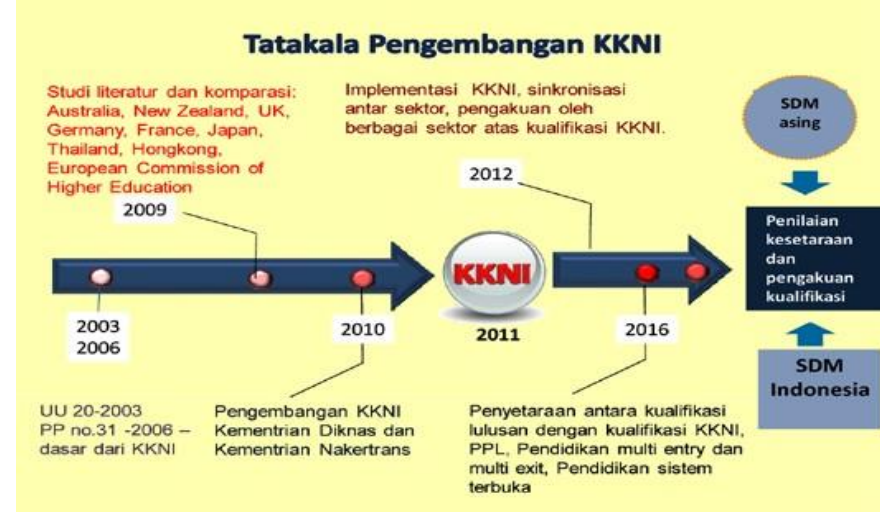

Fig. 1. Indonesian Qualification Framework

\section{METHOD OF RESEARCH}

As this action research on internship in Bali is designed for the compilation of two multidisciplinary text books, the method is multi paradigms. WIR or Work Integrated Learning is providing students the opportunity to benefit from theoretical and academic guidance provided by the textbooks in conjunction with lectures and tutorials and the real world experiences of workplace internships. The text books and adjunct team play a major role in increasing the students' professional competence. It promotes the professional competence standard of university alumni to match those who have extensive work place experience but have limited formal education. Those who does not advance through formal education receive an open system or multi-entry and multi-exit education schemes through out of their career.

\section{RESULT AN DISCUSSION}

\section{A. Population and Tax}

Taxation is somehow problematic. The Kantor Wilayah/tax office at provincial level must reform their tax administration systems. Since the taxation reforms, which started in 2012, the basis of rights and the regulation of national and regional taxation have been modernized. Fig. 2 explains:

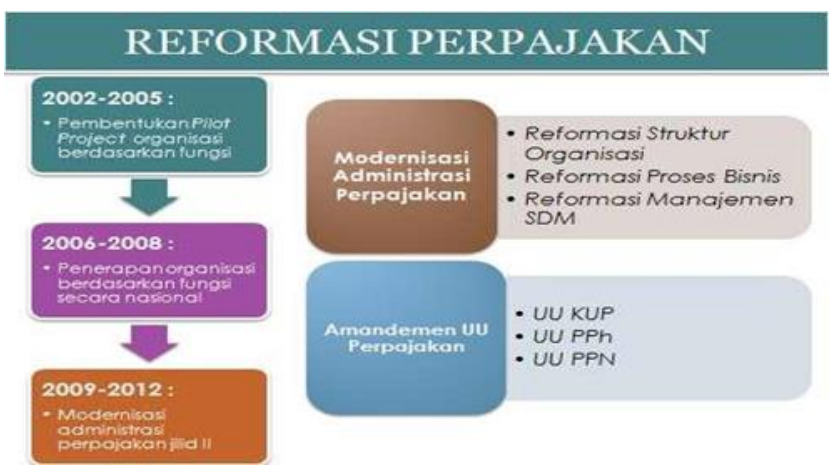

Fig. 2. Tax Reform Source: Tumakaka, 28 May 2015, internship lecture.

The book about 'Population \& Tax' prepares students for their internships and involvement in action research by the four lecturers who wrote the chapters based on their expertise. Six chapters in all are designed to accompany 50 hours of internship made up from 5 hours of work experience per day for 2 days per social institutions. Students who participate in the work experience are given a 2-hour induction seminar by the adjunct team before they commence their internship in the offices of BPS, BKKBN, Disnaker, Dinkes, Dispenda and DJP Bali provincial offices as well as at one Public Accountant office (Kantor Akuntan Publik) in Denpasar. This internship program is expected to increase the students' professional competence. It is also expected to increase the social and political responsibility of students with regard to taxation duties.

One reason for the National Board of Research and Community Intervention, at the Higher Degree Directorate (DITBINLITABMAS) is providing a grant to write this 'Population \& Tax' textbook is that it will promote a wider understanding of the demographic dividend. The demographic dividend comes from a constant increase in population in the productive age groups (15 to 64 years old) resulting in larger tax contribution to the national economy over many years.

Most experts on population studies argue that the demographic dividend should benefit both the workers who pay their taxes and the future development of Indonesia as a whole. As the head of BKKBN/Badan Koordinasi Keluarga Berencana Nasional, Jalal [2] put it, the demographic dividend caused by an increase in the productive age groups and a decrease in child birth over the long run, will see social development support the economic development of Indonesian welfare and prosperity.

The demographic dividend means that the productive age groups contribute to work in society and the economy. The productive age groups are predicted to increase to 68.1 percent of the total population in the period of 20282031 [3]. The students of FISIP UNUD who take this elective subject can be seen as part of the demographic dividend in Indonesia. Their availability and eagerness to work will contribute significantly to the joint 
collaboration between the university and the employers of university alumni. The local government also has an interest in teaching students about how taxpayers contribute to the development of Bali and other provinces in Indonesia.

\section{Literature Review of Population and Tax}

United Nation working papers on human capital strengthening usually concentrate on the method of delivering formal education in developing countries. Dang and Rogers [4] and Goldin [5] explain how human capital strengthening relates to improvements in quality enhancement of population distributions. Goldin illustrates how a natural distribution of population as discussed by Adam Smith (1776) led to the pessimism of Thomas Robert Malthus (1798) in his essay on the principles of population. Goldin [6] elaborates on the classic Malthusian equilibrium as a matter of "stagnant real wages during a long period, small increases in population, and occasional periods of real wage growth followed by increased population and subsequent decreased wages" (2014:4). Unfortunately, this balance of Malthusian theory in Indonesia has been promoted as a bonus demography which means that as the population increases, real income decreases resulting in an increase level of dependency.

By any means, this situation can be three fold. First, those couples who have children when they are young adults allow their children to get married as early as they did (age 16 onward). Second, these shorter generations may put their grandchildren at risk of not receiving tertiary education. Third, the employment available for those who enter the job market early without specific educational background or bilingual ability, offer only low salaries. The result is a vicious cycle that decreases the ability to compete in certain jobs and consequently the outsourcing to replace them.

The prevalence of informal jobs is making livelihoods uncertain in certain sectors; nevertheless, workers have some opportunity in the creative sector, such as fashion, traditional textile, culinary arts, and handicrafts and so on. They work long hours and many people need to work odd jobs; for example, as a healer, masseur, personal cater, and personal child career, or as is done in China, famous brands are copied into three levels of quality $\mathrm{KW} \mathrm{1,2,3}$ in order to sell the goods cheaply. They fulfill the informal sector needs by producing goods that are in demand without importing those branded goods.

Sarwono and Koesoebjono [7] classified working odd jobs as seller in traditional markets, peddler, wrong owner, ojek rider/motorbike taxi, taxi/angkot or bus driver, middle man dealer, shop keeper, household assistance or construction worker, etcetera. Using a Malthusian equilibrium to evaluate the condition of contemporary Indonesia can be misleading because of a national program of birth control and increasing the quality of education and human resources are currently a part of government focus. However, urbanization and a lack of agricultural development can be a hindrance in the long run. Also the number of dependents must decrease as more woman participate in the paid workforce into the future [8].

The development of jobs in a more appropriate Indonesian qualification framework is increasing the quality of life for workers through job enlargement, job enrichment and career possibilities to receive a salary at any level. Take for instance the teaching profession; teachers who enter the job with a bachelor degree get a level III salary as a government employee. Other private sector jobs in banks, manufacturing, construction, and so forth are joining the ranks of those who pay taxes and gradually becoming the middle class of Indonesia. The local government of Bali, for example, has set a minimum wage of Rp1.621.172 per month. In 2015, other provinces have set their minimum wage as follows:

Nangroe Aceh Darusallam Rp. 1.900.000,-

Sumatera Barat Rp. 1.615.000,-

Jambi Rp. 1.710.000,-

Sumatera Selatan Rp. 1.974.346,-

Bangka Belitung Rp. 2.100.000,-

Bengkulu Rp. 1.500.000,-

Banten Rp. 1.600.000,-

Bali Rp. 1.621.172,-

NTB Rp. 1.330.000,-

Kalimantan Selatan Rp. 1.870.000,-

Kalimantan Tengah Rp. 1.896.367,-

Kalimantan Timur Rp. 2.026.126,-

Gorontalo Rp. 1.600.000,-

Sulawesi Utara Rp. 2.150.000,-

Sulawesi Tenggara Rp. 1.652.000,-

Sulawesi Tengah Rp. 1.500.000,-

Sulawesi Selatan Rp. 2.000.000,-

Sulawesi Barat Rp. 1.655.500,-

Maluku Rp. 1.650.000,-

Riau Rp. 1.878.000,-

Sumatera Utara Rp. 1.625.000,-

Lampung Rp. 1.581.000,-

Nusa Tenggara Timur Rp. 1.250.000,-

Kalimantan Barat Rp. 1.560.000,-

Papua Rp. 2.193.000,-

Papua Barat Rp. 2.015.000,-

Maluku Utara Rp. 1.577.617,-

Kepulauan Riau Rp. 1.954.000,-

DKI Jakarta Rp. 2.700.000,- [9]

This data illustrates to students how difficult it is for government and social institutions to manage payments for their growing numbers of workers. At the same time, the minimum wage would only be available for non-tax payers. The taxpayers on the other hand must consider the welfare of the whole population.

\section{Population \& Tax: the text book}

The text book of Population \& Tax has 243 pages. It comprises five chapters of explanation and one chapter of conclusions. In each chapter there is an instructional aim and mind mapping is elaborated. Each chapter starts with a quote from an expert and an introduction before going to the sub-sections of the chapter. In the body of each chapter, there are cases, first reflections, self-reflection and presents a summary of these reflections in boxes to highlight each of them.

Altogether, there are 20 cases, 6 self-reflections and 3 concluding reflections to help students see problems in the field. For example, Chapter 2 and Chapter 3 both include explanations of how populations as numbers or interventions becomes an entity that reflects the 
government's development. On the one hand, an institution such as BKKBN/National Board for Family Planning sends data to the BPS/National Board of Statistics which then can present the information within a broad range of data about the target population. On the other hand, the Dinkes/Health Local Ministry in the city of Denpasar data has several environmental problems and the taxation office can make it clear how the problems need to be solved by money collected as personal tax or corporate tax. The taxation office in every province has their Prathama office based on the number of districts in each province.

In every chapter of the book, there are also informative and illustrative tables, graphs and pictures. In total, the book has 18 tables 13 graphs, and 22 pictures produced by either the author or the lecturer from data sourced from the adjunct team. These illustrations are all in black and white due to color printing costs. In the conclusion of Chapter VI, the four authors provide a summary of their data collection, discussion and conclusions. The lead researcher provides recommendations for future action and research.

The Population and Tax text book is purposely researched and written to be a medium of thought and action for interns. At the end of July 2015, a plenary research workshop was held at FISIP UNUD. The head of the Research Center on Population and Human Resources at Udayana University led the discussion in the workshop. The head of the Taxation Office/Kanwil DJP Bali signed a formal agreement to collaborate with UNUD and invited students of FISIP to undertake their internships at their offices. The head of Kanwil DJP Bali wrote the prologue and epilogue of this book. A second epilogue was contributed by an academic from the Faculty of Economy and Business at Udayana University.

This book is also supervised by the head of the internal auditing unit at the Faculty of Economy and Business at Udayana University. As a supervisor, he was a key architect of the Terms of Reference (ToR) and contributed to each chapter's development. The team met twice a week for 4 months; February, April, May and June 2015. The chapter structure and topics are:

Chapter I: The dynamics of population growth and tax expansion in rural and urban socioeconomic settings. This chapter looks at how Balinese and non-Balinese people in rural and urban dwelling interact with each other. In relation to that, the distribution of employment and unemployment follows a predictable pattern across the province of Bali.

Chapter II: The Human Development Index/IPM as an indicator of the increase of competitiveness in each region. This is a composite index that can be used as an indicator to predict life expectancy in relation to education, literacy derived from schooling, and standards of livelihood.

Chapter III: A demographic surplus in the context of welfare policy and decision making. Better health interventions based on progressive tax rates could make the tax decentralization work in Bali and other provinces so long as the percentage of regional taxes can provide the regions with enough income for development.
Chapter IV: Regulations and rights relate to the transparency and accountability of taxes. The rate of tax is acceptable for everyone if decision makers ensure that tax revenue does actually return to society. All tax payers need to be assured of justice in calculating and reporting their payment of tariffs and taxes. If corrections are necessary, then the procedure must be historically clear and based on justice to the taxpayers.

Chapter V: Progressive tax and a tax payer number/NPWP for individuals and for corporations divided by regional taxation offices. Tax payer numbers are essential to ensure workers and corporations register their payments, calculate and report their cash flows, and make fair tax contributions. For example, land and building taxation in Indonesia is still controversial. In Jakarta and some parts of Java, people build a luxury cemetery and make it as exclusive as possible. Of course, all patterns of consumption are always possible, but sometimes the patterns are unduly shaped by regulations about what can be billed as a tax deduction. Digital codes for various deductions may help consumers to register their luxury goods, including the kick ring or jewelry from germ stones, and make more informed decisions about their consumption.

Chapter VI: Concluding remarks and suggestions. The four writers of this book complete their chapters with a summary. It reminds readers of insights about the data they will come across during their internships or vice versa. The interns can place new data within the general lessons they learn from the textbook. This concluding chapter ends with a suggestion that as a medium of learning, Population \& Tax are urgently necessary to ensure people in the productive age groups (15 to 64 age years) contribute to the tax system.

During the research process for the book, members of the adjunct team from government and social institutions played a crucial part of the internship program. They gave tutorials at the beginning of the internships, while the heads of the various institutions warmly welcomed the internship program. The heads of government departments and institutions allowed free access for the writers to meet with the adjunct team members who themselves were high ranking officials in the institutions. In fact, one senior public accountant was also a member of the adjunct team. Institution List

\begin{tabular}{|l|l|l|l|}
\hline \multicolumn{1}{|c|}{ Institutions } & Persons & \multicolumn{1}{|c|}{ Institutions } & Persons \\
\hline $\begin{array}{l}\text { BKKBN Per- } \\
\text { wakilan Bali }\end{array}$ & Head & $\begin{array}{l}\text { Kanwil DJP } \\
\text { Bali }\end{array}$ & Head \\
\hline $\begin{array}{l}\text { Disnaker } \\
\text { Provinsi Bali }\end{array}$ & Head & $\begin{array}{l}\text { Dispenda } \\
\text { Provinsi Bali }\end{array}$ & HRD \\
\hline $\begin{array}{l}\text { BPS Provinsi } \\
\text { Bali Head }\end{array}$ & $\begin{array}{l}\text { Dinkes Kota } \\
\text { Denpasar }\end{array}$ & Head \\
\hline
\end{tabular}

In making both text books available, the leader of the research team established a two-step process:

Before 31 July 2015, the nine authors wrote drafts of each chapter. Before the seminar on 31th July, publication cover dummies, Fig. 3, were made in Yogyakarta.

During and after August 2015, the nine authors and the research leader finalized the drafts of each chapter and each book as a whole and put the document into the UNESCO format. The two books went to Udayana University Press at the end of September 2015. 


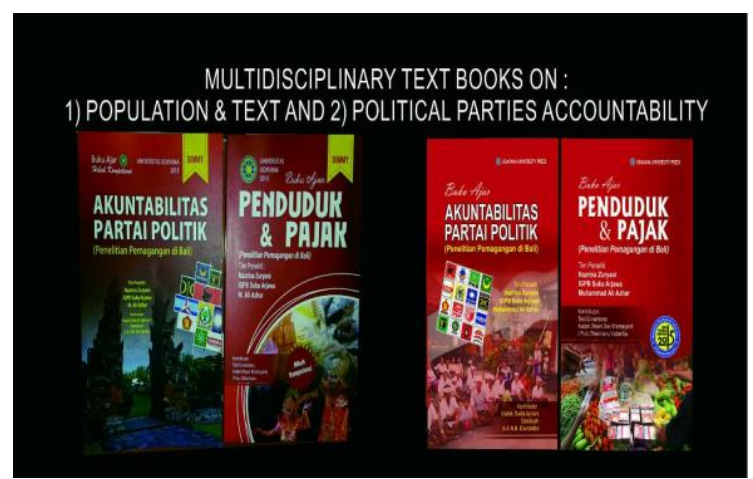

Fig. 3. Proposed Text Book Covers

\section{B. Political Parties Accountability}

Accountability does not only concern financial administration. It also concerns a number of other aspects of an institution, campaign source, the regeneration of cadre, and internal auditing. Our research focused on the internship of students in six institutions. The adjunct team consists of the heads of KPU, Bawaslu, Kesbangpol, Ombudsman, Public Accountants Wayan Budiartha, and the Democratic Party, Bali branch. The novelty of this textbook is that it is based on the placement of students in each of these institutions. The proposal to put forward "Political Party Accountability" as an elective subject for students in FISIP will also improve the quality of education at Udayana University.

\section{Literature Review on Indonesian Contemporary Politics}

Following Weber's thought on the $19^{\text {th }}$ development of legal-rational political parties, Firmazah [11] inquired into the communication and positioning of ideology in contemporary Indonesian political parties. Especially since the New Oder regime for 32 years -- the Suharto era - Golkar (Functional Group) has become a dominant political party along with two other political parties, namely PPP and PDI+P.

The reformation era since 1998 has seen the transformation of the contemporary Indonesia political system into a democratic system. Alongside the three dominant parties, the mushrooming number of small political parties could be regarded as an indicator of popular awareness of the importance of political accountability and transparency. Gradually since 1998, the former dominance of the New Order ruling party, Golkar, has diminished.

There are several drivers to look more closely at the condition of political parties in Indonesia. As a compressor type of party, Golkar was a 'machine for creating projects' during the New Order and constituted a clear example of what is now known as KKN, Kolusi (Collusion), Korupsi (Corruption) and Nepotisme (Nepotism) in Indonesian political history. Golkar has allowed accumulation and ownership of the natural resources of Indonesia to be in the hands of a small number of computers. It is undeniable that, within each political party, conflict of interest has arisen over who finances the party's campaigns, who runs for office, and who gets a share of power to make decisions that affect particular businesses and industries. These interests have little concern for either the welfare of Indonesians or the rule of law in Indonesia. Beside Golkar as the party of economic, administrative, and military elites, the two other dominant parties are the Islam-based party called PPP, Partai Persatuan Pembangunan (Development Collaboration Party) and the PDI-P (Fight for Indonesia Democratic Party).

The birth of the KPK, Komisi (Commission) for Pemberantasan (Eradication) of Korupsi (Corruption) was the most important development during the initial period of office during the presidency of Susilo Bambang Yudhoyono (SBY). Before SBY, just after the Suharto era, the founding father Sukarno's daughter, Megawati Soekarnoputri, turned the PDI into PDI-P (Partai Demokrasi Indonesia Perjuangan). The three now dominant parties, Golkar, PPP and PDIP, cultivated alliances with other small political parties and made the leader of Partai Demokrat (Democrat Party), SBY, the president of Indonesia. After the elections of 2009, Nasdem (National Democrat) and Democrat parties were among 48 parties to gain representation in the national assembly. In the 2014 election, only 12 political parties gained representation and together they chose between Joko Widodo (from PDI+P) and Prabowo Subianto (from Gerindra/People Movement in Indonesia). In the end, Jokowi became the president of Indonesia.

Mardiasmo [12] elaborates on how accountability is part of a leader's transparency to the public. The separation of powers between the executive, the legislature, and the judiciary ensures each of these three arms of government have checks and balances in place. This allows popular control over government as a whole, and pushes each to be an agent of development on behalf of the Indonesian constituency. Indonesians need to better representatives to fulfill community aspirations for better legislators. Those legislators come from political parties and play a big role in turning people's various demands, expectations, and hopes into legal actions. However, legislators seem to have a low sense of responsibility to their voters. Too often they work in the parliament to enrich their party and to benefit themselves.

Reflecting critically on the condition of Western European politics before World War II, Meny and Knapp [13] concluded that: "A democratic system without political parties or with a single party is impossible or at any rate hard to imagine" (1998, 86). The word "accountability" addresses the criticism of Meny and Knapp. In the new millennium, the phrase "good governance" similarly addresses the interaction between public representatives, public administrators, and private corporations. This book looks first at accountability for probity and legality as a means to avoid abuse of power. Second, it looks at legal accountability for political parties relating to many aspects of law besides financial accountability for public funds. Third, it looks at procedures to ensure that public funds for political parties are controlled internally and externally with better auditing systems. Those political parties who use public funds must make them work for the community and society in a fast, rigorous, responsive, and open fashion. Without these minimal indicators of probity, legality, and auditing, the potential for KKN, collusion, corruption and nepotism, is all too strong.

Under the aegis of the KPK, all the political parties must acquire a total awareness of accountability. Many 
users of social media are also promoting the eradication of KKN among the political parties' candidates at all provincial elections on 9 December 2015. However, the practices of many political cadres in Indonesia are still ambiguous. There are many social media postings about the elites who are promoted to be local leaders, but then suffer legal punishment during their tenure for the corruption they became involved with. Fig.4 lists political cadres who were involved in corruption cases, but are still running for provincial election on 9 December 2015

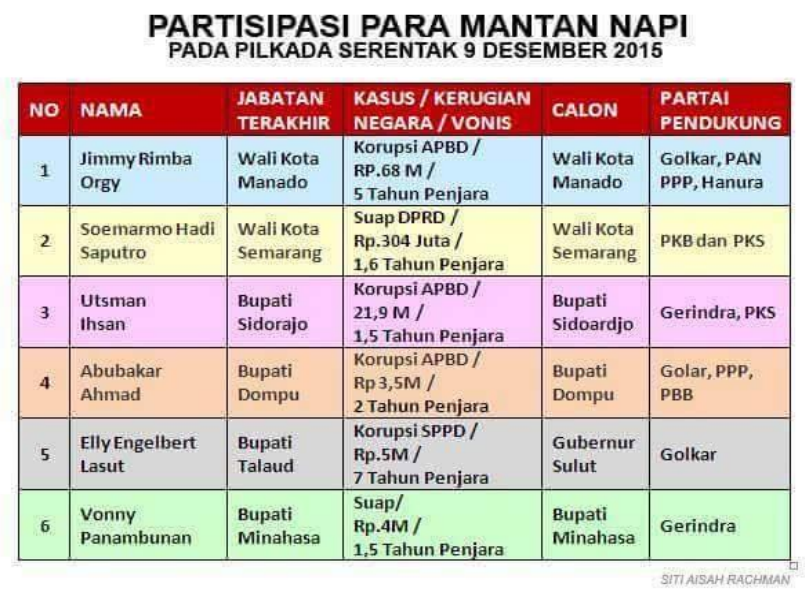

Fig. 4. List of Election Candidates involved in corruption cases Agung Bawantara 2015

\section{Data from Other Sources}

Transparency International has conducted polling within the Pol-Tracking Institute (January 2014). Almost 44.75 percent of respondents said that they will never elect candidates from political parties with any accountability problems. The data show that the cadres who become leaders in the provinces of Indonesia still seem to include many problematic people, as the Table II lists.

TABLE I. LIST OF CANDIDATE PAIRS FOR ALL TOGETHER PROVINCIAL ELECTION

\begin{tabular}{|l|l|l|}
\hline No. & \multicolumn{1}{|c|}{$\begin{array}{c}\text { Political Parties } \\
\text { Cadre of }\end{array}$} & $\begin{array}{c}\text { Total of Problematic Person (as } \\
\text { a pair) }\end{array}$ \\
\hline 1 & PDI-P & 60 \\
\hline 2 & PAN & 56 \\
\hline 3 & Nasdem & 52 \\
\hline 4 & Demokrat & 52 \\
\hline 5 & Gerindra & 49 \\
\hline 6 & PK Sejahtera & 47 \\
\hline 7 & Hanura & 46 \\
\hline 8 & PKB & 42 \\
\hline 9 & Golkar & 33 \\
\hline 10 & PKPI & 26 \\
\hline 11 & PBB & 22 \\
\hline 12 & PPP & 15 \\
\hline \multicolumn{2}{|l|}{ TOTAL } & 500 persons \\
\hline
\end{tabular}

\section{Text Book of Political Party Accountability}

The New Political Party Accountability text book has 162 pages, consist of five chapters, concerning a) political party accountability, b) institutional accountability, c) financial funding and strategy of political parties d) creating quality political party cadre and e) internal control systems in financial accounting, and the sixth chapter is concluded remarks. Among the six writers of the book, one is an internal auditor of the Faculty of Economy and Business at Udayana University.

In summary, the writing of each chapter related directly to the internship program. Table 3 shows the meeting schedule.

TABLE II. SCHEDULE OF MEETING AND INTERNSHIP SCHEDULE

\begin{tabular}{|l|l|l|l|}
\hline \multicolumn{1}{|c|}{$\begin{array}{c}\text { Name of } \\
\text { Institution }\end{array}$} & $\begin{array}{c}\text { Date of } \\
\text { Meeting }\end{array}$ & Reception by & \multicolumn{1}{|c|}{$\begin{array}{c}\text { Internship } \\
\text { scedule }\end{array}$} \\
\hline $\begin{array}{l}\text { DPP Demokrat } \\
\text { party }\end{array}$ & 29 April & $\begin{array}{l}\text { Secretary \& 3 } \\
\text { cadres }\end{array}$ & 22 and 23 May \\
\hline Ombudsman & 30 April & Head & 13 May \\
\hline $\begin{array}{l}\text { Komisi Pemilihan } \\
\text { Umum/KPU }\end{array}$ & 30 April & $\begin{array}{l}\text { Head of Com- } \\
\text { mission+ staffs }\end{array}$ & 20 May \\
\hline Kesbangpol Bali & 05 May & Head of subdit & 26 and 27 May \\
\hline $\begin{array}{l}\text { Kantor Akuntan } \\
\text { Publik Ketut } \\
\text { Budiartha April }\end{array}$ & $\begin{array}{l}\text { Prof. Dr. Ketut } \\
\text { Budiartha, SE, } \\
\text { M.Ak }\end{array}$ & 19 and 21 May \\
\hline Bawaslu Bali & 4 May & Head & 14 May \\
\hline
\end{tabular}

c. Source: [15] Zuryani, dkk. 2015 Laporan Kemajuan Penelitian Pemagangan Buku Ajar

\section{CONCLUSIONS}

The method of research for this project imitates the Australian University's approach on Work Integrated Learning (WIL) by facilitating student internship in tandem with on campus lecture attendance. Furthermore, both the text books regarding Population \& Tax and the Political Party Accountability incorporate multidisciplinary discourses. By asking the Adjunct team to deliver the teaching in the field, those students who are in the productive age groups were informed of the economic burden carried by their nation's development. In parallel with this, the Adjunct team also elaborated on ideal leadership characteristics of political parties to help develop ideal democracy of Indonesia. As the result of this way of thinking, writing these two text books will increase the competence of the lecturers in the team. The research findings confirm our confidence that these two textbooks are needed for teaching the students of FISIP about the current situation of the population, taxation and political parties in Indonesia.

In conclusion, producing a relevant instrument of thought for the internship programs in the form of these textbooks is important. Therefore, learning that "Population and Tax", are a part of the human capital development of Indonesia, as is the bonus of the demographic dividend which could benefit all is an important catalyst for change. It is also important to generate a wide range of understanding about "the accountability of political parties" where leaders who are corrupt can be prosecuted by KPK and the justice system. The internship of students could also increase the awareness of political cadres and participation.

\section{ACKNOWLEDGMENTS}

Thank you for Kemenristek Dikti especially to the Ditbinlitabmas who funded these text books, allowing them to be finished in time. My appreciation to all at Udayana University who is directly involved in the making of these books (lecturers who are the authors, Dean of FISIP, Dean of FEB, the reviewers for the two books, the consultant from FEB, head and staffs of LPPM). Thanks also to those who are not directly involved, but fully support this internship program. I am 
in debt to the adjunct team who are giving lectures at their institutions, and the heads of BKKBN, BPS, Disnaker, Kanwil DJP Bali, Dinkes Denpasar, Dispenda, the Ombudsman of Bali, Demokrat Party, KPU Bali, Kesbangpol, Bawaslu KAP Wayan Budiartha, Finally, to the students of FISIP Udayana University, thank you for good behavior and disciplined attendance.

\section{REFERENCES}

[1] McLennan, B and B Keating 2009. Work-Integrated Lear ning (WIL) in Australian Universities: the challenges of mainstreaming WIL,ALTC NAGCAS National Symposium June 2008 - Melbourne retrieved on 28 December 2015 http://eprints.usq.edu.au/id/eprint/541

[2] Jalal, F. 2015. Indonesia Memiliki Indeks Ketidaksetaraan Gender (IKG) Tinggi, Jurnal Perempuan, Gathering SJP ke XI retrieved on 30 June 2015 www.jurnal perempuan.org.

[3] Alisahbana, A. 2014. Puncak Bonus Demografi, Hindari Indonesia dari Middle Income Trap, retrieved on 2 March 2015 www.infobanknews.com/2014/ 02/puncak-bonus-demografihindari-indonesia-dari-middle-income-trap/.

[4] Dang, H \& FH Rogers. 2008. How to Interpret the Growing Phenomenon of Private Tutoring: Human Capital Deepening, Inequality Increasing, or Waste of Resources. The World Bank, Policy Research Working Paper \# 4530. USA: Development Research Group.

[5] Goldin, C. 2014. Human Capital, Handbook of Cliometrics, retrievd on $20 \quad$ September sholar.harvard.edu/files/goldin/files/human _capital_handbook_of_cliometrics_0.pdf.

[6] Goldin, C. 2014. Human Capital, Handbook of Cliometrics, $\begin{array}{llll}\text { retrieved } & \text { on } & 20 & \text { September } \\ 2015\end{array}$ sholar.harvard.edu/files/goldin/files/human _capital_handbook_of_cliometrics_0.pdf.

[7] Sarwono, S dan S. Koesoebjono. Pajak: Sumber Penghasilan Negara bagi Pembangunan. Opini \& Editorial, p. 11. Thursday, 13 Agustus 2015. Jakarta: Suara Pembaruan.

[8] Jalal, F. 2015. Indonesia Memiliki Indeks Ketidaksetaraan Gender (IKG) Tinggi, Jurnal Perempuan, Gathering SJP ke XI retrieved on 30 June 2015 www.jurnal perempuan.org.

[9] (http://dhonypratama.com/upah-minimum-regional-).

[10] Zuryani, N. IGPB Suka Arjawa and M A Azhar. 2015. Progress Report in the Making of Textbooks and Internship Program, Competence Scheme. Jakarta: Ditbinlitabmas.

[11] Firmanzah. 2011. Mengelola Partai Politik Komunikasi dan Positioning Ideolgi Politik di Era Demokrasi. Jakarta: Yayasan Pustaka Obor Indonesia.

[12] Mardiasmo, 2002. Akuntansi Sektor Publik. Yogyakarta: Andi Offset.

[13] Meny, Y \& A Knapp. 1998. Government and Politics in Western Europe: Britain, France, Italy, Germany, third edition. USA: Oxford University Press, p. 86.

[14] Tempo Weekly, 21 August, 2015. 